\title{
THE RESPECTIVE CONTRIBUTION OF SMOOTH AND STRIATED COMPONENTS IN THE URETHRAL PRESSURE PROFILE OF THE SPINAL CORD INJURED. A NEUROPHARMACOLOGICAL AND URODYNAMIC STUDY ${ }^{\star}$
}

\author{
By A. B. Rossier, B. A. Fam, I. Y. Lee, M. Sarkarati and D. A. Evans. \\ Urodynamics Laboratory, Spinal Cord Injury Service, Veterans Administration \\ Medical Center, West Roxbury and the Departments of Orthopaedic Surgery and \\ Medicine, Harvard Medical School, Boston, Massachusetts.
}

Key words: Neuropathic bladder; Urodynamics; Urethral pressure profile; Pudendal blocks; Alpha-adrenergic receptors.

TWENTY-FOUR spinal cord injury patients with a complete lesion, and thirteen with an incomplete lesion underwent urodynamic investigations with interrupted urethral pressure profile, vesical, intra-rectal and anal pressure recordings with electromyography of the external anal and urethral sphincters. Simultaneous bladder and urethral pressure profile recordings were carried out with the radiopaque urethral marker successively but alternatively positioned under fluoroscopy at the vesico-urethral junction (VUJ), the prostatic urethra (UI), the mid membranous urethra (U2) and the distal part of the membranous urethra (U3) (Rossier et al., I980). Recordings were carried out before and after Io $\mathrm{mg}$ intravenous injection of phentolamine, pudendal nerve blocks with bi-lateral injection of $20 \mathrm{ml}$ Marcaine ${ }^{\circledR} 0.5$ per cent with epinephrine $1 / 200000$, or a combination of both to evaluate the respective contribution of the sympathetic and somatic innervation to the maximum urethral closure pressure (MUCP) in U2 and in $\mathrm{U}_{3}$. The technique of interrupted catheter withdrawal has permitted a demonstration of the gradient of pressures in the membranous urethra itself with base line mean $\mathrm{U}_{3}$ pressure higher than $\mathrm{U}_{2}$ pressure by $15.7 \mathrm{I} \mathrm{cm}$

TABLE I

Phentolamine injections after previous pudendal blocks during the same examination indicate different percentages of drop of the remaining pressures in $\mathrm{U}_{2}$ and $\mathrm{U}_{3}$ after pudendal blocks alone

\begin{tabular}{ccc}
\hline \multirow{2}{*}{ Tests } & \multicolumn{2}{c}{ Drop of pressure in } \\
\cline { 2 - 3 } & $\mathrm{U}_{2}$ & $\mathrm{U}_{3}$ \\
\hline $\begin{array}{c}\text { Phentolamine (I4 patients) } \\
\text { Pudendal blocks + phentolamine (9 patients) }\end{array}$ & $39 \%$ & $47 \%$ \\
a) Pudendal blocks ALONE & $6 \mathrm{I} \%$ & $48 \%$ \\
b) With additional Phentolamine & $29 \%$ & $5 \mathrm{I} \%$ \\
\hline
\end{tabular}

* Summary of a paper read at the Annual Scientific Meeting of the International Medical Society of Paraplegia, Athens, Greece. October 1982. 
$\mathrm{H}_{2} \mathrm{O}(\mathrm{p}<0 . \mathrm{O}$ ). These results emphasize that the interrupted withdrawal technique is superior to the continuous withdrawal technique in upper motor neuron paralysed bladder (UMNB). $U_{2}$ striated and smooth muscle components were shown to represent about 60 and 30 per cent of the MUCP respectively. In $\mathrm{U}_{3}$ striated and smooth components are more abundant than in $\mathrm{U}_{2}$ and contribute in equal proportion to the MUCP, that is, about 50 per cent (Table I). In the lower motor neuron paralysed bladder the greatest pressure drop in $\mathrm{U}_{2}$ and $\mathrm{U}_{3}$ following phentolamine was thought to be due to the so-called denervation supersensitivity law (Cannon, 1939). Following pudendal blocks the disappearance of sphincter dyssynergia in the presence of uninhibited waves shows that dyssynergia is mediated through pudendal nerves via spinal reflex arcs. Further evidence is provided by incomplete pudendal blocks with persistance of dyssynergia which eventually disappeared following complete blocks whereas the uninhibited bladder pattern remained unchanged. In some patients the injection of phentolamine during bladder contractions was accompanied for a few minutes by the abolition of spontaneous uninhibited bladder activity together with the disappearance of sphincter dyssynergia. In addition, in all but two patients bladder tone did not decrease following phentolamine. Our clinical observations parallel experimental results which led to the assumption that both excitatory and inhibitory adrenergic receptors were present in the bladder of cats (Edvardsen, I968). Our findings in spinal man show that under physiological conditions of bladder activity blockade of alpha-adrenergic receptors, presumably excitatory, may depress vesical smooth muscle function and tone. This leads us to conclude that blockade of alpha-adrenergic receptors inhibit primarily the transmission in vesical and/or pelvic parasympathetic ganglia and act secondarily through direct depression of the vesical smooth muscle, since bladder tone is known to be an intrinsic property of bladder muscle. In the majority of cases the absence of vascular oscillations recorded in $\mathrm{U}_{2}$ and $\mathrm{U}_{3}$ following phentolamine or pudendal blocks was not paralleled by a decrease in blood pressure. It must therefore be secondary to the diminution in resistance recorded in the membranous urethra which is pharmacologically relaxed and to which Poiseuille's law should apply. Previous experimental data in dogs (Tulloch, I974) as well as our observations allow us to conclude that the vascular bed does not contribute to any major extent to the resistance recorded in the membranous urethra. Whether or not the sympathetic system participates in the innervation of the external urethral sphincter in man still remains conjectural. Our clinical observations support recent histochemical findings carried out in fresh human biopsies which led the author to conclude that 'In the human, noradrenergic innervation of urethral striated muscle cannot be observed' (Klück, I980). Smooth and striated muscles have been shown to be equal in proportion in $\mathrm{U}_{3}$. Following pudendal blocks the pressure dropped by 48 per cent, and by an additional $5 \mathrm{I}$ per cent following phentolamine. Should the striated component also be under some adrenergic control a much greater drop in pressure should have taken place since each of phentolamine injections and pudendal blocks alone caused about a 50 per cent drop in pressure. By the same token since a higher proportion of striated muscle has been demonstrated in $\mathrm{U}_{2}$ the addition of phentolamine to pudendal blocks should have resulted in a drop of pressure more pronounced than 29 per cent 
(Table). To conclude, the neuropharmacological results of this study raise strong doubts as to the existence of a sympathetic innervation of the striated urethral sphincter in man.

\section{REFERENCES}

Cannon, W. B. (1939). A law of denervation. Am. F. Sci., 198, 737-750.

EDVARDSEN, P. (1968). Nervous control of urinary bladder in cats. III. Effects of autonomic blocking agents in the intact animal. Acta Physiol. Scand., 72, 183-193.

KLÜCK, P. (1980). The autonomic innervation of the human urinary bladder, bladder neck and urethra: a histochemical study. Anat. Record, 198, 439-447.

Rossier, A. B., Fam, B. A., DiBenedetto, M. \& Sarkarati, M. (1980). Urethrovesical function during spinal shock. Urol. Res., 8, 53-65.

Tulloch, A. G. S. (1974). The vascular contribution to intraurethral pressure. Brit. F. Urol., 72, 659-664. 